\title{
Proximate composition of commercially important fish species in southern Gulf of Lake Tana, Ethiopia
}

\author{
Hirut Geremew ${ }^{1, *}$, Melesse Abdisa ${ }^{2}$, and Goraw Goshu ${ }^{1}$ \\ ${ }^{1}$ College of Agricultural and Environmental Sciences and Blue Nile Water \\ Institute, Bahir Dar University, Bahir Dar, Ethiopia. \\ ${ }^{2}$ Graduate Program of Food Science and Nutrition, Addis Ababa University, \\ Addis Ababa, Ethiopia.
}

\begin{abstract}
The aim of the study was to determine the proximate composition of each sex of Oreochromis niloticus, Clarias gariepinus and Labeobarbus intermedius fish species from the southern Gulf of Lake Tana, Ethiopia. The fish samples were collected during the dry season of 2014 from the three fish landing sites, i.e., Bata, Micheal and Giorgis, where local fishermen sell their catches. Species were identified via morphological examination and color. Sexes were identified by observing genital papilla and gonads after dissection. After measuring weight and length of young fish species, fish weighing 201-310 g were selected for the study. A total of 72 fish, eight and four fish per species and sexes were selected, respectively, for each site. The sample size was determined using "resource equation" method. Only edible fillet was labeled and transferred to plastic bags according to species and sex. Then the sample was transported for proximate analysis to Addis Ababa Food Science and Nutrition laboratory using icebox at about $4{ }^{\circ} \mathrm{C}$. Fish sample composites were prepared by taking the fish samples from the three fish landing sites for each sex and species. Samples were thawed at room temperature and oven-dried at $60{ }^{\circ} \mathrm{C}$ for $72 \mathrm{~h}$, then ground into a fine powder. Proximate composition was determined following the procedure of Association of Official Analytical Chemists (AOAC). Data analysis was conducted using analysis of variance (ANOVA). Nutrient content significantly varied among fish species; more protein was recorded from $O$. niloticus and fat from $L$. intermedius. Also, fat, ash and gross energy content were different between sexes; female fish contained significantly more fat and gross energy than males. In conclusion, consumers are advised to consume these species to obtain required nutrients.
\end{abstract}

Keywords: Fish species, Lake Tana, Proximate composition.

DOI: https://dx.doi.org/10.4314/ejst.v13i1.4

\footnotetext{
* Corresponding author: rutaenat2006@gmail.com

(C)This is an Open Access article distributed under the terms of the Creative Commons Attribution License (http://creativecommons.org/licenses/CC BY4.0)
} 


\section{INTRODUCTION}

In Ethiopia, household food insecurity, hunger and under nutrition remain critical issues; the poor nutritional status of women and children has been a consistent problem (Ali et al., 2013). Protein malnutrition is severe because the intake of foods from animal sources was low in the country (Herrador et al., 2015). Fish are good source of protein, polyunsaturated fatty acids particularly omega-3 fatty acids, Calcium, Zinc and Iron. Next to other animal meat, fish is the only protein source that contains all the essential amino acids in the right proportion, so-called complete protein. It is also the sole accessible and affordable source of animal protein for the poor (Thilsted et al., 2014). Fish in developing countries like Ethiopia provide important nutrients to a large number of people and contribute for nutrition security. Fish are considered high nutrient sources for humans that contribute for low blood cholesterol and reduce the risk of stroke and heart diseases (Aberoumand, 2012). Determination of some proximate profiles such as protein, lipid, ash and other nutrient contents is often necessary to make sure that they are within the range of dietary requirement and commercial specifications. Different researches done in Ethiopia lakes revealed that fish are good source of protein, fat and ash (Kassahun Asaminew et al., 2012; Alemu Lema et al., 2013; Tsegay Teame et al., 2015). Lake Tana is home of 28 fish species including 17 endemic Labeobarbus species. Current fish production of Lake Tana was 1,454 tons per year (Asefa Mitike, 2014). However, there was no study conducted in Lake Tana on the proximate composition of commercially important fishes. Therefore, the present study was carried out to investigate the nutritional value of commercially important fish species of each sex of fish species from the southern Gulf of Lake Tana.

\section{MATERIALS AND METHODS}

The study was conducted in Lake Tana, Bahir Dar, Amhara Regional State (about $565 \mathrm{~km}$ North West of Addis Ababa), situated at an altitude of 1800 meters above sea level. It is located at $11^{\circ} 29^{\prime} \mathrm{N}$ Latitude and $37^{\circ} 29^{\prime}$ E longitudes (Tesfahun G/Michael and Demissie Sewmehon, 2004). Lake Tana, the largest lake in Ethiopia and the 
source of Blue Nile River, has a surface area of $c a .3200 \mathrm{~km}^{2}$. It is situated in the northwestern highlands at an altitude of approximately $1800 \mathrm{~m}$. It is a shallow lake (maximum depth $14 \mathrm{~m}$, mean $8 \mathrm{~m}$ ). More than 60 small seasonal tributaries and seven perennial rivers (Gumara, Ribb, Megech, Gelgel Abbay, Gelda, Arno-Garno, and Dirma) feed the lake. The potential for fish production of Lake Tana is estimated to be 10,000 tons per annum. However, the current production is only about 1,454 tons per year (Asefa Mitike, 2014). Nile tilapia (Oreochromis niloticus), African catfish (Clarias gariepinus) and species flock of endemic, large Labeobarbus spp. were the three main species targeted by commercial gillnet fishery of Lake Tana and these forms $65 \%, 20 \%$ and $15 \%$ of the annual catch compositions of fish species (Dereje Tewabe, 2015).

\section{Collection of samples}

The fish samples were collected from Southern Gulf of Lake Tana which is southern part of the Lake in Northwestern Ethiopia. The study was conducted in the dry season of the year 2014. Fish samples were collected from the three fish landing sites, i.e., Bata, Micheal and Giorgis, where local fishermen sell their fishes. The three commercially important fish species Oreochromis niloticus, Clarias gariepinus and Labeobarbus intermedius were selected for this study. Identification of fish species and sexes were done by the help of an expert from Fisheries and Other Aquatic Life Research Center, Bahir Dar, Ethiopia. Fish species were identified via morphological examination and color. Sexes for $C$. gariepinus, O. niloticus were identified based on their genital papilla before dissection. For $L$. intermedius sexes were identified by observing gonads after dissection. The length and weight of the fish was measured using weighing balance and measuring board (Table 1). Young fish weighing 201-310 g were used for this study (Allumma and Idowu, 2011). A total of 72 fish were bought from the three fish landing sites (Bata, Micheal and Giorgis). Then, 24 fish were collected for each species from the three fish landing sites. This means eight fish and four fish for every species and sexes, respectively. The sample size was determined through "resource equation" method (Charan and Kantharia, 2013) and calculated as follows. The value of E should lie between 10 and 20 .

$\mathrm{E}=$ Total number of animals - Total number of groups 
$E=72-3=69$, which was more than 20 hence sample size in this study was more than necessary.

Selected fish samples were immediately cut up and only edible fillet was labeled and transferred to plastic bags according to sexes of each species. The samples were kept in an icebox at about $4{ }^{\circ} \mathrm{C}$, then transported to Addis Ababa, Food Science and Nutrition Laboratory for proximate analysis.

Table 1. Weight and length of the studied fish species in southern gulf of Lake Tana.

\begin{tabular}{llll}
\hline Species & Local name & Mean weight $(\mathrm{g})$ & Mean length $(\mathrm{cm})$ \\
\hline O. niloticus & Kereso & $243.5 \pm 45.2$ & $23.71 \pm 1.2$ \\
C. gariepinus & Anbasa & $280.3 \pm 31.2$ & $34.14 \pm 1$ \\
L. intermedius & Niche assa & $252.1 \pm 50.1$ & $28.95 \pm 2.3$ \\
\hline
\end{tabular}

\section{Preparation of samples}

In order to obtain representative fish sample composites were prepared by taking the fish sample from the three fish landing sites (Bata, Micheal and Giorgis) for each sex of fish species. Fillets of each sex of fish species were thawed at room temperature and samples were oven-dried at $60{ }^{\circ} \mathrm{C}$ for $72 \mathrm{hrs}$. Each sex of fish species samples was dried then ground into a fine powder using porcelain mortar and pestle. Then powdered fillets were kept in polyethylene bags for proximate analysis. Proximate analysis was done in triplicate for each sex of fish species.

\section{Proximate composition analysis}

\section{Moisture content}

Moisture content was determined by oven drying method following the procedure of AOAC (1995). Empty dishes were dried using air drying oven for 1 hour at $105^{\circ} \mathrm{C}$, transferred to the desiccators (with granular silica gel), cooled for 30 minutes, and were weighed. Replicates of the minced samples were mixed thoroughly and $5 \mathrm{~g}$ of composite fresh fillet was transferred to the dried and weighed dishes. The dishes and their contents were placed in the drying oven and dried for $3 \mathrm{~h}$ at $105^{\circ} \mathrm{C}$ in an oven until constant weights were obtained, and 
then the dishes and their contents were cooled in desiccators to room temperature and reweighed. The moisture content was determined by measuring the weight of a sample before and after the water was removed by evaporation:

$$
M C=\frac{(W W S-W D S) \times 100}{W W S}
$$

Where, $\mathrm{MC}=$ Moisture content, WWS $=$ Weight of wet sample, WDS $=$ Weight of dried sample

\section{Crude protein}

Crude protein in the sample fish fillets was quantified following the procedure of AOAC (1995) by Kjeldahl methods; $0.5 \mathrm{~g}$ of powdered fish fillet was weighed into Kjeldahl digestion flask and then digested by heating at $370{ }^{\circ} \mathrm{C}$ for four hours in the presence of $6 \mathrm{ml}$ Sulfuric acid, $3.5 \mathrm{ml} \mathrm{H}_{2} \mathrm{O}_{2}, 3 \mathrm{~g}$ of catalyst Copper Sulfate $\left(\mathrm{CuSO}_{4}\right)$ and Potassium sulfate $\left(\mathrm{K}_{2} \mathrm{SO}_{4}\right)$. After digestion was completed, the clear solution formed was cooled for 30 minutes and neutralized by adding $25 \mathrm{ml} \mathrm{NaOH} \mathrm{(40 \% )} \mathrm{and} \mathrm{diluted} \mathrm{using} 25 \mathrm{ml}$ distilled water. Twentyfive $\mathrm{ml}$ distilled water, $25 \mathrm{ml}$ Boric acid and 3 drops of Methyl blue were added to a receiving $250 \mathrm{ml}$ capacity flask connected to the distiller by tube. The distillation process was terminated when the volume of receiving flask reached between 200 to $250 \mathrm{ml}$. Note: all reagents were added to the blank except the sample. The nitrogen content was estimated by titration of the borate anion formed with $0.1 \mathrm{~N} \mathrm{HCl}$. The amount of Nitrogen was calculated using the formula:

$$
\% N=\frac{N \mathrm{HCl} \times(\mathrm{Vol} \mathrm{HCl} \mathrm{TS}-\mathrm{Vol} \mathrm{HCl} \mathrm{TB}) \times 14 \mathrm{~g} \times 100}{\text { Gram of sample mole }}
$$

Where, $\mathrm{TS}=$ titrates sample, $\mathrm{TB}=$ titrates blank.

Crude protein $=6.25 \times \mathrm{N}$.

\section{Crude fat}

Crude fat was determined following the procedure of AOAC (1995) by semi continuous solvent extraction method (Soxhlet method). Accordingly, for all sample categories, $2 \mathrm{~g}$ of dried and ground sample was placed in a porous cellulose extraction thimble and thimble was covered with fat free cotton. The thimble was placed in 
an extraction chamber which was suspended above a flask containing the solvent ( $50 \mathrm{ml}$ of diethyl ether) and below a condenser. The flask which was dried in drying oven at $105^{\circ} \mathrm{C}$ containing boiling chips was placed inside the extraction chamber and heated at $55^{\circ} \mathrm{C}$ and the solvent evaporated and moved up into the condenser where it was converted into a liquid that trickled into the extraction chamber containing the sample. At the end of the extraction process, which typically lasted for 3 hours, the flask containing the solvent and lipid was removed, the solvent was evaporated in drying oven at $70{ }^{\circ} \mathrm{C}$ and the mass of lipid remaining was quantified gravimetrically and calculated from the difference in weight of the extraction flask before and after extraction as percentage. The crude fat in the initial sample was calculated as:

$$
\text { Fat content }=\frac{\text { Weight of fat } \times 100}{\text { Weight of sample }}
$$

\section{Ash content determination}

To determine the ash content, AOAC method (AOAC, 1985) was used. Briefly, duplicates of $2.50 \mathrm{~g}$ of homogenized samples were placed in pre-washed, dried, weighed and marked crucibles, to be ash at $550{ }^{\circ} \mathrm{C}$ in Muffle Furnace for eight hours. Then, samples were cooled in desiccator and weighed again. The ash content was calculated as follows:

$$
\% \text { Ash }(\text { wet basis })=\frac{(W A A-T W C) \times 100}{\text { Original sample weight }}
$$

Where, WAA $=$ weight after ashing, $\mathrm{TWC}=$ tare weight of crucible.

Eventually proximate composition in wet base was recalculated from dry base using the formula:

$$
\% \text { Proximate in wet }=\frac{\% P I D \times(100-M C)}{100}
$$

Where, $\mathrm{PID}=$ Proximate in dry, $\mathrm{MC}=$ Moisture content.

\section{Gross energy value}

Gross energy values ( $\mathrm{kcal} / \mathrm{g}$ ) was calculated by overall addition of the protein content multiplied by 4 and the total lipids content multiplied by 9 and using Atwater's conversion factors (Atwater \& Benedict, 1902). The result was expressed as kcal per $100 \mathrm{~g}$.

Gross energy value $=(4 \times$ protein content $)+(9 \times$ fat content $)$ 


\section{Statistical analysis}

Variation in nutrient content among species and between sexes was analyzed using two-way ANOVA and means separated using Duncan's Multiple Range test.

\section{RESULTS AND DISCUSSION}

\section{Nutrient content in relation to fish species}

Proximate composition significantly varied among the fish species (Table 2). O. niloticus gave significantly more protein (18.82\%) and L. intermedius more fat $(2.36 \%)$. C. gariepinus gave significantly less protein $(15.2 \%)$, fat $(1.76 \%)$ and ash $(1.3 \%)$ compared to the other two fish species.

Table 2. Mean \pm SE proximate composition in percent and gross energy (GE) content in $\mathrm{kcal} / 100 \mathrm{~g}$ of $O$. niloticus, C. gariepinus and L. intermedius fillet in wet basis $(\mathrm{N}=24$ each).

\begin{tabular}{lllll}
\hline Protein & Moisture & Fat & Ash & Gross energy \\
\hline $\begin{array}{l}\text { O. niloticus } \\
18.8 \pm 0.01^{\mathrm{a}}\end{array}$ & $79.0 \pm 0.03^{\mathrm{b}}$ & $0.6 \pm 0.02^{\mathrm{c}}$ & $1.4 \pm 0.01^{\mathrm{a}}$ & $79.8 \pm 0.07^{\mathrm{b}}$ \\
$\begin{array}{l}\text { C. } \text { gariepinus }^{\mathrm{a}} \\
15.2 \pm 0.01^{\mathrm{c}}\end{array}$ & $80.5 \pm 0.03^{\mathrm{a}}$ & $1.8 \pm 0.02^{\mathrm{b}}$ & $1.3 \pm 0.01^{\mathrm{b}}$ & $76.7 \pm 0.07^{\mathrm{c}}$ \\
$\begin{array}{l}\text { L. }_{\text {intermedius }} \\
15.4 \pm 0.01^{\mathrm{b}}\end{array}$ & $80.4 \pm 0.03^{\mathrm{a}}$ & $2.4 \pm 0.02^{\mathrm{a}}$ & $1.4 \pm 0.01^{\mathrm{a}}$ & $83.1 \pm 0.07^{\mathrm{a}}$ \\
\hline
\end{tabular}

Means within a column with the same letter(s) are not significantly different from each other at $\alpha=0.05$.

The protein content in this study was above $15 \%$ in all studied fish species. That indicates they were a rich source of protein (Stancheva and Merdzhanova, 2013). Similar protein content of O. reochromis $(18.5 \%)$ was reported before in Lake Ziway (Erkihun Massresha et al., 2017). In the current study, moisture content $(80.45 \%)$ was higher than previous reports in other lakes of Ethiopia (Alemu Lema et al., 2013; Tsegay Teame et al., 2016; Erkihun Massresha et al., 2017). High moisture makes fish products vulnerable to microbial spoilage, oxidative degradation of polyunsaturated fatty acids and therefore lowers quality and shelf life (Olagunju et al., 2012). According to (Ackman, 1989) fish can be grouped into four categories based on their fat content: lean fish $(<2 \%)$, low fat ( 2 to $4 \%$ ), medium fat (4 
to $8 \%$ ), and high fat ( $>8 \%$ ). Based on the present study, O. niloticus and C. gariepinus were classified as lean, whereas L. intermedius was low fat fish species. Gross energy value was higher on $L$. intermedius as compared to the other two fish species. This is because $L$. intermedius contained significantly higher fat than others. In general, proximate composition was significantly varied among the studied fish species. This may be due to consumption or absorption capability and conversion potentials of essential nutrients from their diets or their local environment (Adewoye and Omotosho, 1997; Tsegay Teame et al., 2016).

\section{Nutrient content in relation to species and sex interaction}

Fat, ash and gross energy contents of fish fillet varied significantly between sexes (Table 3), but not moisture and protein contents. Females contained significantly more fat and gross energy than males. In contrast, amount of ash was significantly more in males.

Table 3. Mean \pm SE proximate composition in percent and gross energy (GE) content in $\mathrm{kcal} / 100 \mathrm{~g}$ of fish species and sex of fish fillet in wet basis.

\begin{tabular}{|c|c|c|c|c|c|}
\hline $\begin{array}{l}\text { Species } \\
\text { /Sex }\end{array}$ & Moisture $^{\text {NS }}$ & Protein $^{N S}$ & Fat & Ash & $\begin{array}{l}\text { Gross } \\
\text { energy }\end{array}$ \\
\hline \multicolumn{6}{|c|}{ O. niloticus } \\
\hline Male & $79.1 \pm 0.46$ & $18.9 \pm 0.58$ & $0.5 \pm 0.05^{\mathrm{a}}$ & $1.5 \pm 0.07^{\mathrm{a}}$ & $80.0 \pm 2.4^{\mathrm{a}}$ \\
\hline Female & $77.6 \pm 0.46$ & $19.9 \pm 0.58$ & $0.7 \pm 0.05^{\mathrm{b}}$ & $1.0 \pm 0.07^{\mathrm{b}}$ & $85.8 \pm 2.4^{\mathrm{b}}$ \\
\hline \multicolumn{6}{|c|}{ C. gariepinus } \\
\hline Male & $81.4 \pm 0.46$ & $14.0 \pm 0.58$ & $0.8 \pm 0.05^{\mathrm{a}}$ & $0.7 \pm 0.07^{\mathrm{a}}$ & $63.6 \pm 2.4^{\mathrm{a}}$ \\
\hline Female & $80.0 \pm 0.46$ & $14.7 \pm 0.58$ & $2.3 \pm 0.05^{\mathrm{b}}$ & $0.9 \pm 0.07^{\mathrm{b}}$ & $79.9 \pm 2.4^{b}$ \\
\hline \multicolumn{6}{|c|}{ L. intermedius } \\
\hline Male & $81.0 \pm 0.46$ & $14.5 \pm 0.58$ & $1.5 \pm 0.05^{\mathrm{a}}$ & $1.0 \pm 0.07^{\mathrm{a}}$ & $71.8 \pm 2.4^{\mathrm{a}}$ \\
\hline Female & $80.0 \pm 0.46$ & $16.0 \pm 0.58$ & $3.2 \pm 0.05^{\mathrm{b}}$ & $1.1 \pm 0.07^{\mathrm{b}}$ & $94.0 \pm 2.4^{b}$ \\
\hline
\end{tabular}

According to previous studies, nutrient content of female fish was higher than male fish (Ayas et al., 2012; Alemu Lema et al., 2013; Pereira et al., 2013). Exogenous factors affect fish body composition. However, intrinsic factors like sex greatly affect fish body composition since they have various influences on physiological processes (Huss, 1995; Naeem et al., 2011; Tsegay Teame et al., 2016). 


\section{CONCLUSION}

From the present study it can be concluded that there was significant variation among fish species and sexes in proximate composition. $O$. niloticus had significantly more protein compared to both $C$. gariepinus and L. intermedius fish species. Female fish contained significantly more fat and gross energy as compared to male fishes. From a nutritional point of view, the three fish species demonstrated acceptable quality particularly $O$. niloticus showed the highest protein and ash content compared to other species. Consumers could secure their nutrition by consuming these fish species. Generally, further study is required to investigate other chemical and biological parameters to ensure the quality and the safety of those fishes.

\section{ACKNOWLEDGEMENTS}

The authors would like to acknowledge Blue Nile Water Institute, Bahir Dar University for funding the project.

\section{REFERENCE}

Aberoumand, A. (2012). Proximate composition of less known some processed and fresh fish species for determination of the nutritive values in Iran. Journal of Agricultural Technology 8(3): 917-922.

Ackman, R.G. (1989). Nutritional composition of fats in seafoods. Progress in Food Nutrition Science 13:161-241.

Adewoye, S.O and Omotosho, J.S. (1997). Nutrient composition of some freshwater fishes in Nigeria. Bioscience 11(4):333-336.

Alemu Lema, Melese Abdisa and Gulelat Dessa. (2013). Effect of endogenous factors on proximate composition of Nile tilapia (Oreochromis niloticus L.) fillet from Lake Zeway. American Journal of Research Communication 1(11): 405-410.

Ali, D., Saha, K.K., Nguyen, P.H., Diressie, M.T., Ruel, M.T., Menon, P and Rawat, R. (2013). Household food insecurity is associated with higher child undernutrition in Bangladesh, Ethiopia, and Vietnam, but the effect is not mediated by child dietary diversity. The Journal of Nutrition 143(12):2015-2021.

Allumma, M.I and Idowu, R.T. (2011). Prevalence of Gills helminth of Clarias gariepinus in Baga side of Lake Chad. Journal of Applied Sciences of Environmental Management 15:47-50. 
AOAC International. (1995). AOAC (Association of Official Analytical Chemists) International; Arlington; 16th edition. Volume 2.USA.

Asefa Mitike. (2014). Fish production, consumption and management in Ethiopia. International Journal of Economics and Management 3: 183.

Atwater, W.O and Benedict, F.G. (1902). Experiments on the metabolism of matter and energy in the human body. Government Printing Office, Washington DC.

Ayas, D., Ozogul, Y., Ozogul, I and Uçar, Y. (2012). The effects of season and sex on fat, fatty acids and protein contents of Sepia officinalis in the northeastern Mediterranean Sea. International Journal of Food Sciences and Nutrition 63(4): 440-445.

Charan, J and Kantharia, N.D. (2013). How to calculate sample size in animal studies. Journal of Pharmacol Pharmacother 4:303-6.

Dereje Tewabe. (2015). Status of Lake Tana Commercial Fishery, Ethiopia. International Journal of Aquaculture and Fishery Sciences 1(1): 012020.

Erkihun Massresha, Hintsa, M., Paul, L and Ashagrie Zewdue. (2017). Proximate composition and fatty acid content of commercially important fish species from Ethiopian Lakes. World Journal of Food Science and Technology 1(3): 105-114.

Herrador, Z., Perez-Formigo, J., Sordo, L., Gadisa, E., Moreno, J., Benito, A., Aseffa, A and Custodio, E. (2015). Low dietary diversity and intake of animal source foods among school aged children in Libo Kemkem and Fogera districts, Ethiopia. Public Library of Science 10(7): 1-18.

Huss, H.H. (1995). Quality and quality changes in fresh fish. FAO. Rome pp: 348.

Kassahun Asaminew, Waidbacher, H and Zollitsch, W. (2012). Proximate composition of selected potential feedstuffs for small-scale aquaculture in Ethiopia. Livestock Research for Rural Development 24(106).

Naeem, M., Rasul, A., Salam, A., Iqbal, S., Ishtiaq, A., Khalid, M and Athar, M. (2011). Proximate analysis of female population of wild feather back fish (Notopterus notopterus) in relation to body size and condition factor. African Journal of Biotechnology 10(19).

Olagunju, A., Muhammad, A., Bello, S., Mohammed, A., Abdullahi Mohammed, H and Mahmoud, K.T. (2012). Nutrient composition of Tilapia zilli, Hemi- synodontis membranacea, Clupea harengus and Scomber scombrus consumed in Zaria. World Journal of Life Sciences and Medical Research 2:16-9.

Pereira, T.G., Batista, I., Bandarra, N.M., Ferreira, J., Fradinho, N and Afonso, F. (2013). Chemical composition and nutritional value of raw and fried allis shad (Alosa alosa). International Journal of Food Science and Technology 48(6):1303-1308.

Stancheva, M., Merdzhanova, A., Petrova, E., Petrova, D. (2013). Heavy metals and proximate composition of Black Sea Sprat. Bulgarian Journal of Agricultural Science 19: 35-41. 
Thilsted S.H., James D., Toppe J., Subasinghe R., Karunasagar I. (2014). Maximizing the contribution of fish to human nutrition. ICN2 Second International Conference on Nutrition: Better Nutrition Better Lives, Rome, Italy.

Tsegay Teame, Natarajan, P., Zelealem Tesfay (2016). Proximate and mineral composition of some commercially important fish species of Tekeze Reservoir and Lake Hashenge, Ethiopia. International Journal of Fisheries and Aquatic Studies 4(1): 2394-0506.

Tesfahun G/Michael and Demissie Sewmehon, (2004). Lake Tana: A socioeconomic synopsis. Amhara Regional Agricultural Research Institute, Bahir Dar, Paper presented to The Lake Tana Resource Management Workshop, Bahir Dar, Ethiopia 